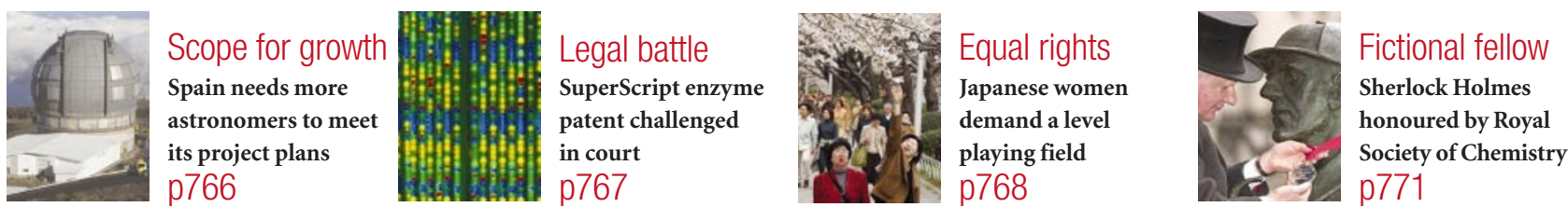

\title{
Universities face cash shortfall as stock-market slide hits charities
}

\section{Declan Butler}

When stock markets surged in the 1990s, philanthropic donations became one of the fastest-growing sources of funding for research and new laboratories throughout the world. But with stocks now staggering towards their third consecutive yearly loss, this growth has gone into reverse sending shock waves through labs that have depended on it.

Universities and colleges in the United States received about one-sixth of the $\$ 212$ billion that Americans gave to charity in 2001, according to Giving USA, a report compiled by the Center on Philanthropy at Indiana University, Bloomington.

Although hard data for 2002 are not yet available, Vance Peterson, president of the Washington-based Council for Advancement and Support of Education, predicts that this year will be "the first year in the last 30 where giving towards higher education and research has dropped". According to one survey, eight of the top ten US foundations reduced their grant-giving last year, and more cuts are expected.

Instead of planning for growth, most of the talk at philanthropic organizations is of toughing out the current crisis by making cuts or freezes in jobs, grants, building and research, until the economic outlook brightens. But the situation varies widely between organizations. The Seattle-based Bill and Melinda Gates Foundation, for example, which has pledged large sums to AIDS- and malaria-vaccine research, reports that most of its \$24-billion endowment is held in bonds, and has therefore been unaffected by the slump in share prices.

Others are less well placed. The biggest losers include foundations set up by a new breed of 'Silicon Valley' philanthropist (see Nature 410, 140-143), whose wealth was based on high-technology stocks. The David and Lucile Packard Foundation in Los Altos, California, for example, has seen its assets mostly Hewlett Packard stocks - fall from $\$ 13.1$ billion in 1999 to just $\$ 3.5$ billion. It intends to continue supporting activities it views as top priorities, including its Fellowships for Science and Engineering Program

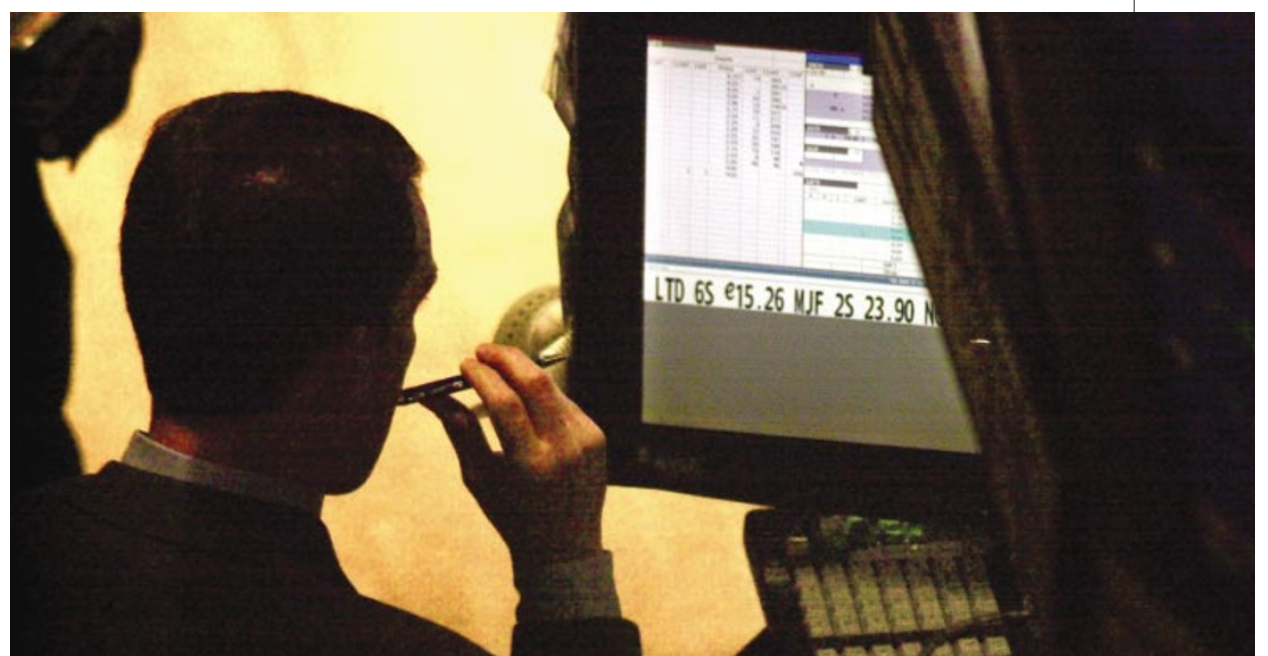

Hard figures: falling stock values have cut into the resources of many philanthropic organizations.

and the Monterey Bay Aquarium Research Institute. But the foundation says that it is reducing its staff of 160 by half, and will distribute $\$ 200$ million in grants in 2003 , down from $\$ 250$ million this year.

Some smaller foundations could be extinguished altogether. The San Jose-based Kirsch Foundation, for example, which was founded in 1999 by the Silicon Valley entrepreneur Steven Kirsch, has seen the value of its endowment fall from $\$ 95$ million in 2000 to around $\$ 15$ million. According to the foundation's president Kathleen Gwynn, its operating budget will exhaust these funds in a few years if markets do not recover and Kirsch is unable to provide more money.

The Howard Hughes Medical Institutethe largest US research philanthropic organization, with an annual budget of $\$ 665$ million - is currently "assessing the impact of sustained market volatility and lowered investment income on its programmes in biomedical research and science education", according to spokeswoman Avice Meehan. It has frozen recruitment at its headquarters in Chevy Chase, Maryland. Other large US philanthropic agencies declined to comment, but the Rockefeller Foundation, for example, reduced its grant funding by onefifth to $\$ 120$ million in 2001.
Across the Atlantic, the portfolio of Europe's biggest research charity, the Londonbased Wellcome Trust, fell from $£ 15$ billion (US $\$ 23$ billion) in 2000 to $\mathfrak{E} 12$ billion last year, and may drop again this year.

Most charities try to even out their ups and downs by managing funds on a five-toten-year basis, says Diana Garnham, chief executive of the UK Association of Medical Research Charities. "There is unlikely to be a sudden drop in their research programmes, she says, "but if the stock market continues to underperform, then we can expect to see a downturn." The impact will be most keenly felt by smaller charities, she adds.

Wealthy research universities face a double blow: the value of their endowment funds is falling in many cases, even as the incoming flow of new money dries up. US universities experienced an average drop in their endowments last year of $3.6 \%$, according to figures compiled by the National Association of College and University Business Officers.

Fund managers had some success in limiting the damage, though — the Standard \& Poor's (S\&P) 500 stock index, the best measure of US stock values, fell by $14.8 \%$ in the same period. But with the S\&P down by almost a quarter so far this year, university endowments are still shrinking in value. 